\title{
KEBIJAKAN FISKAL ZAKAT DAN PAJAK PADA PEREKONOMIAN: \\ (Studi Komparatif Ekonomi Islam, Klasik dan Keynes)
}

\author{
Eko Suprayitno
}

Fakuttas Ekonomi Universitas Islam Negeri (UIN) Malang,

Jl. Gajayana 50 Telp. 0341-551354 Malang. email:Eko_prayitno457@yahoo.com

Abstract

This papers analyses studies difference of analysis policy of fiscal religiousobligatory (zakat) and tax in chartered investment counsel Clasik, Keynes and Islam chartered investment counsel. In Islam chartered investment counsel there are componen religious obligatory which must be packed into model calculation earnings nsaional, because religious obligatory that with existence of religious obligatory will give contribution larger ones in economics through effect multiplier compared to chartered investment counsel system Klasik and Keynes which only apply tax. Next, this paper argues that given the requirements of Muslim countries a direct tax and zakat on personal consumption expenditure. It would be comparative effect of direct taxes and zakat on their systems. Its introduction would help in financing a high level of economic development. Since it is highly anti-inflationary, its introduction would help in controlling inflation and achieving much desired price stability. More importantly, an expenditure tax by favouring saving vis-à-vis consumption would expand zakat base. In order to realise these advantages an attempt is made in this paper to develop a workable model of an expenditure tax and zakat which would incorporate within itself the shariah based prescriptions. Profit and loss sharing, categorization of saving schemes and creation of national equity fund are some of its prominent features.

Key words: fiscri policy, zakat, comparative sudy, islam, classic and eyness

Ulul Albab, Vol. 9 No. 2, 2008 


\section{Pendahuluan}

Ekonomi konvensional di bawah dominasi kapitalisme saat ini sedang menghadapi masa krisis dan reevaluasi. Sebagaiman disebut sebelumnya, kapitalisme menghadapi serangan kritikan dari berbagai penjuru. Mulai dari Karl Max sampai pada era tahun 1940-an,1950-an, 1960an, bahkan di awal abad 21 kritikan tersebut semakin tajam dan meluas. seperti Joseph Schumpeter, Daniel Bell, Irving Kristol, Gunnar Myrdal, Paul Omerod, Umar Ibrahim Vadillo, Critovan Buarque, sampai kepada Joseph Stigliz (Agustianto, 2006: 45).

Banyak indikasi kegagalan kapitalisme tersebut, antara lain. pertama, Ekonomi konvensional yang berlandaskan pada sistem ribawi, ternyata semakin menciptakan ketimpangan pendapatan yang hebat dan ketidakadilan ekonomi. Kedua, Ekonomi kapitalisme tersebut juga telah menciptakan krisis moneter dan ekonomi dibanyak negara. Di bawah sistem kapitalisme, krisis demi krisi terjadi terus menerus, sejak tahun 1923, 1930, 1940, 1970, 1980, 1990, 1997 bahkan sampai sekarang. Banyak negara senantiasa terancam krisis susulan dimasa depan jika sistem kapitalisme terus dipertahankan.

Ketiga, Ekonomi kapitalisme banyak memiliki kekeliruan dan kesalahan dalam sejumlah premisnya, terutama rasionalitas ekonomi yang telah mengabaikan dimensi moral.

\section{Ketimpangan Pendapatan}

Ketimpangan pendapatan tersebut dari tahun ke tahun semakin menganga dan melebar. Hal itu terlihat dari data World Bank tahun 2004. Pada tahun 1965 , sebesar $20 \%$ orang terkaya menguasai 69,5 pendapatan dunia. Pada tahun 1970 menjadi $70 \%$. Pada tahun 1980 ketimpangan makin tajam di mana $20 \%$ orang terkaya tersebut mendominasi $75,4 \%$ pendapatan dunia, dan pada tahun 1990 ketimpangan pendapatan semakin tajam lagi, yaitu 83,4\%. (Data lengkap bisa dilihat pada Tabel. 1). 
Tabel 1. Proporsi Pendapatan

\begin{tabular}{lcccc} 
& \multicolumn{4}{c}{ Percentage of Total World Income } \\
Population & 1965 & 1970 & 1980 & 1990 \\
& 2.3 & 2.2 & 1.7 & 1.4 \\
Poorest 20\% & 2.9 & 2.8 & 2.2 & 1.8 \\
Second Poorest 20\% & 2.9 & 3.9 & 3.5 & 2.1 \\
Third richest 20\% & 4.2 & 21.3 & 18.3 & 11.3 \\
Second richest 20\% & 21.2 & 70.0 & 75.4 & 83.4 \\
Richest 20\% & 69.5 & 70 & & \\
Sumber: World Bank (1998). & & & &
\end{tabular}

Sementara itu, $20 \%$ orang termiskin pada tahun 1965 menguasai 2,3\% income dunia. Selanjutnya di tahun 1970 , terjadi penurunan, mereka mengusai $2,2 \%$. Pada tahun 1980 terus terjadi penurunan, mereka hanya mengusai $1,7 \%$ dari total income dunia. Kesenjangan semakin terjadi di tahun 1990, mereka hanya mengusai 1,4 \% .Pada tahun 2000-2005 diprediksikan, mereka hanya bisa menguasai $1 \%$ saja.

Ketimpangan pendapatan di bawah ekonomi kapitalisme juga terlihat pada data IRTI IDB (2004), bahwa 15 persen penduduk dunia hidup dengan pendapatan per kapita per hari sebesar 7080 dolar AS. Pada umumnya mereka hidup di negara-negara Barat. Sementara sisanya, yaitu sekitar 85 persen, harus terpaksa hidup dengan pendapatan per kapita per hari di bawah 5 dolar AS. Kebanyakan diantara mereka tinggal di wilayah negara-negara berkem-bang yang mayoritas muslim.

Jika sistem tersebut dipertahankan terus, ketimpangan tetap akan terjadi, bahkan bisa lebih tajam lagi. Untuk itulah para pakar ekonomi mene-gaskan bahwa untuk memperbaiki keadaan ini, tidak ada jalan lain kecuali mengubah paradigma dan visi, yaitu melakukan satu titik balik peradaban sebagaimana yang diteriakkan Fritjop Chapra. Titik balik perdaban menis-cayakan dilakukannya pembangunan dan pengembangan sistem ekonomi yang memiliki nilai dan norma yang bisa dipertanggungjawabkan.

Ulul Albab, Vol. 9 No. 2, 2008 


\section{Kemiskinan dan Pengangguran}

Selain data World Bank di atas, fakta di Asia Timur pada tahun 1990, juga menunjukkan keadaan ekonomi yang tragis. Hampir 170 juta anak laki-laki dan perempuan putus sekolah pada tingkat sekolah menengah. Di Asia Tenggara dan Pasifik lebih sepertiga anak-anak berusia di bawah lima tahun mengalami kekurangan nutrisi. Hampir satu juta anak-anak di Asia Timur mati sebelum berumur lima tahun. Memang bisa saja dikemukakan argumen bahwa seiring dengan perjalanan waktu dan semakin meningkatnya pertumbuhan, kekurangan-kekurangan itu akan bisa dihilangkan. Akan tetapi hal demikian nampaknya lamunan belaka, sebab kalau memang demi-kian, maka negara-negara industri pasti akan terbebas dari masalahmasalah seperti itu. Pada kenyataannya dewasa ini lebih dari 100 juta orang di negara-negara industri hidup di bawah garis kemiskinan dan lebih dari lima juta orang menjadi tunawisma.

Peristiwa depresi hebat telah memperlihatkan secara jelas kelemahan logika Hukum Say dan konsep laissez faire. Ini dibuktikan oleh ekonomi pasar yang hampir tidak mampu secara konstan menggapai tingkat full employment dan kemakmuran. Ironisnya, di balik kemajuan ilmu ekonomi yang begitu pesat, penuh inovasi, dilengkapi dengan metodologi yang semakin tajam, model-model mate-matika dan ekonometri yang semakin luas untuk melakukan evaluasi dan prediksi, ternyata ilmu ekonomi tetap memiliki keterbatasan untuk meng-ambarkan, menganalisa maupun memproyeksikan kecenderungan tingkah laku ekonomi dalam perspektif waktu jangka pendek (Chapra, 2002: 153).

Dengan kata lain, ilmu ekonomi, bekerja dengan asumsi-asumsi ceteris paribus. Dalam konteks ini, Keynes pernah mengatakan, "Kita terkungkung dan kehabisan energi dalam perangkap teori dan implementasi ilmu ekonomi kapitalis yang ternyata tetap saja mandul untuk melakukan terobosan mendasar guna mencapai kesejahteraan dan kualitas hidup umat manusia di muka bumi ini". 


\section{Gagalnya Kapitalisme}

Dengan melihat realita di atas, jelas ada "something urong" dalam konsepkonsep yang selama ini diterapkan di berbagai negara, termasuk Indonesia, karena kelihatan masih jauh dari yang diharapkan. Konsep-konsep tersebut terlihat tidak memiliki konstribusi yang cukup signifikan, bahkan bagi negara-negara pencetus konsep tersebut. Ini terbukti dari ketidakmampuan direali-sasikannya sasaran-sasaran yang diinginkan seperti pemenuhan kebutuhan dasar, kesempatan kerja penuh (full employment) dan distribusi pendapatan dan kekayaan merata.

Konsep-konsep tersebut juga dianggap gagal, karena menyuburkan budaya eksploitasi manusia atas manusia lainnya, kerusakan lingkungan serta melupakan tujuan-tujuan moral dan etis manusia. Singkatnya, konsep yang ditawarkan Barat, bukanlah pilihan tepat apalagi dijadikan prototype bagi negara-negara yang sedang berkembang. Namun demikian kita tak boleh menafikan bahwa pengalaman dari ekonomi pembangunan yang telah berkembang itu banyak yang bermanfaat dan penting bagi kita dalam membangun, meskipun relevansinya sangat terbatas.

Sistem kapitalis maupun sosialis jelas tidak sesuai dengan sistem nilai Islam. Keduanya bersifat eksploitatif dan tidak adil serta memperlakukan manusia bukan sebagai manusia. Kedua sistem itu juga tidak mampu menjawab tantangan ekonomi, politik, sosial dan moral di zaman sekarang. Hal ini bukan saja dikarenakan ada perbedaan ideologis, sikap moral dan kerangka sosial politik, tetapi juga karena alasan-alasan yang lebih bersifat ekonomis duniawi, perbedaan sumberdaya, stuasi ekonomi internasional yang berubah, tingkat ekonomi masing-masing dan biaya sosial ekonomi pembangunan.

Teori pembangunan seperti yang dikembangkan di Barat, banyak dipengaruhi oleh karakteristik unik dan spesifik, juga dipengaruhi oleh nilai dan infra struktur sosial politik ekonomi Barat. Teori demikian jelas tidak dapat diterapkan persis di negara-negara Islam. Terlebih lagi, sebagian teori pembangunan Barat lahir dari teori kapitalis. Karena kelemahan 
mendasar inilah, maka teori tersebut tidak mampu menyelesaikan persoalan pem-bangunan di berbagai negara berkembang.

Ketika sistem ekonomi kapitalisme mengalami kegagalan maka peluang ekonomi syariah makin terbuka luas untuk menjadi solusi kerusakan eko nomi dunia. Diharapkan para ilmuwan dan praktisi ekonomi Islam saat ini dapat memanfaatkan peluang besar yang sangat strategis itu dengan jihad iqtishadi dan ijtihad yang lebih kreatif dan inovatif dalam koridor syari'ah ilahiyah. Penerapan ekonomi Islam di Indonesia dalam bentuk perbankan syariah dan penerapan zakat.

Namun pada intinya mengemukakan hal yang sama, yaitu mengaitkan pengeluaran pemerintah dengan pajak. Artinya, melalui pajak, pemerintah tidak sekedar mengumpulkan dana, namun membangun barang publik yang dapat memuaskan masyarakat. Dengan demikian, dimensi dari pajak ada dua yaitu (1) penyediaan dana dan (2) mewujudkan beban pajak yang mencerminkan kepuasan masyarakat terhadap suatu barang publik.

Dalam perspektif seperti itu, zakat hanya memenuhi dimensi pertama. Di sisi lain, kita menemukan bahwa seluruh masyarakat khususnya negara yang sedang berkembang haus atau kekurangan sumber dana, mengejar masyarakat yang maju serta mengharapkan hasil yang tinggi. Kita menemukan kemampuan perseorangan ternyata merupakan pembentengan yang terbesar dan pembebasan diri dari beban persaingan lebih besar dan lebih kuat.

Zakat merupakan sumber dana yang mantap pencairannya baik secara sukarela maupun wajib. Jika pengeluaran zakat kepada pemerintah secara sukarela banyak terjadi karena ketaatan kaum muslimin pada pendekatan hati mereka lebih kuat dari pada pengorbanan apapun, akan tetapi adanya pengingkaran pembayaran zakat mengharuskan penguasa (pemerintah) untuk mengambilnya secara paksa (dengan kekuatan) sebagaimana yang telah dilakukan oleh khulafa al-Rasyidin Abu Bakar, yaitu mengisyaratkan perang kepada mereka yang ingkar zakat dan disifatkan sebagai satu kemurtadan (Masy'hur, 2002: 346).

Ulul Albab, Vol. 9 No. 2, 2008 


\section{Pengaruh Zakat terhadap Perekonomian}

Pelaksanaan kegiatan pertumbuhan ekonomi, kesejahteraan dalam memakmurkan negara dan masyarakat diperlukan adanya penggabungan seluruh potensi manusia dan material. Hal itu dimaksudkan bahwa pelaksanaan usaha pertumbuhan ekonomi dengan semaksimal mungkin memerlukan tersedianya kualitas dan kuantitas yang seimbang dari kemampuan manusia, sumber-sumber alam serta material.

Zakat adalah mengatasi sumber-sumber pendanaan yang lain, karena dai berperan sebagai sumber yang teratur, melimpah hasilnya, pengalokasian yang sudah ditentukan dan dapat memenuhi keperluan-keperluan pendanaan pengembaangan ekonomi dalam cakupan yang sangat besar. Berbeda dengan pajak, yang pendayagunaannya tidak terbatas, sehingga orang yang mampu pun dapat memperoleh bagian dari pajak. Ekonomi Islam menjadi istimewa karena adanya sumber penting ini yang tidak ada duanya dalam ekonomi manapun.

\section{Zakat Memerangi Usaha (Kegiatan) Penimbunan}

Penimbunan harta adalah bagian dari pendapatan yang tidak terkonsumsi, yakni sia-sia dan tidak boleh diulang produktivitasnya, akan tetapi malah dia tersimpan dalam kondisi tidak digunakan secara ekonomi. Penimbunan harta ini juga dianggap sebagai kendala-kendala yang menghambat pengembangan ekonomi. Hal itu karena ekonomiekonomi ini menghadapi kemerosotan/penurunan pendapatan dan kemudian penurunan tingkat simpanan dan secara khusus disebabkan munculnya penimbunan yang memenuhi simpanan dalam bagian kecil yang masih ada sisa pendapatan setalah dikonsumsi. Dan menambah kesukaran pada masalah ini adalah karena tidak adanya pengarahan atau tujuan dari simpanan-simpanan yang telah mantap pada pengembangan produktif tetapi diarahkan pada bagian dalam apa yang sering disebut investasi pasif. Dan ini terbentuk dalam penim-bunan emas, membangun rumah yang megah, pembelian tanah, penimbun-an-penimbunan sumber mata uang asing. 
Sebagian pakar menyatakan pengaruh penimbunan sebagai pembekuan urat nadi ekonomi (Economic Arteriosolerosis). Dan penimbunan memiliki efek dan pengaruh yang sama dalam usaha ekonomi, baik penimbunan tersebut dalam level perseorangan ataupun dalam level nasional. Ibnu Khaldun mengemukakan pengertian penimbunan dan penahanan harta secara nasional, kemudian dai berkata:

"Maka harta berputar antara rakyat dan raja/pemimpin dari mereka ke dia dan dari dia ke mereka sehingga apabila seorang raja/pemimpin membekukan maka rakyat kehilangan, sebagai sunnah untuk hambahambanya":

Teori-teori ekonomi modern sepakat dengan teori yang dikemukakan Ibnu Khaldun dalam kita Muqaddimahnya selama 6 abad. Maka teori-teori tersebut telah sampai membahas efek dari penimbunan salah satu sumbersumber masyarakat terutama modal pribadi dan negara yang berupa efekefek negatif terhadap taraf kegiatan ekonomi, dimana penimbunan sebagian pendapawan dalam bentuk simpanansimpanan yang non-produktif, begitu pula suatu penimbunan akan mengakibatkan berkurangnya taraf kegiatan ekonomi yaitu terjadinya penyusutan dan praktek ekonomi terhambat.

Islam memiliki alat yang positif untuk mememerangi usaha penimbunan. Alat tersebut adalah zakat. Zakat menjadi ancaman bagi modal (kapimal) yang ditimbun dengan kepunahan dalam waktu yang tidak lebih dari 40 tahun. Dan apabila harta itu tidak diikutsertakan dalam kegiatan ekonomi yang sedang berjalan dan berkembang secara halal sebagai hasil keikutsertaannya sesuai dengan penggunaannya yang ditentukan oleh Allah SWT.

Selain itu, zakat memainkan peranan penting dalam memerangi penimbunan harta melalui terapi psikis dan sosial bagi para penimbun, maka zakat menghindarkan mereka dari kotoran-kotoran hati yang keras, akibat harta yang mereka timbun. Dengan demikian maka zakat merupakan ben-teng bagi diri seorang muslim dari sifat rakus dan tamak dan pengaruh yang mendorongnya serta memisahkan diri dari masyarakat. Disamping 
itu, peran-an zakat dalam memerangi penimbunan harta tidak hanya sejauh jiwa masyarakat, akan tetapi meluas sampai pada ekonomi yang nampak dalam sektor pengumpulan dan pembelanjaan.

Dari sisi pengumpulan harta, zakat berusaha memerangi penimbunan harta dan menghadapi pembekuan harta yang hanya berputar/beredar di antara orang-rang kaya. Hal tersebut dikuatkan dengan apa yang kita saksikan dalam ekonomi makro, yang berupa bahaya-bahaya yang diakibatkan oleh hanya beredarnya harta diantara orang-orang kaya terhadap taraf kegiatan ekonomi. Di sisi lain, kita menemukan bahwa terfokusnya ukuran besar dari harta di tangan individu-individu tertentu akan berakibat keterpaksaan berhutang dari mereka. Dan mereka tidak menghutangi orangorang yang berhutang selagi tidak menyerahkan denda atau bagian tertentu atau riba sebagai gantiuang yang mereka berikan, kemudian mereka menuntunya dengan disertai denda.

\section{Peranan Zakat dalam Mendorong Investasi}

Kewajiban zakat sangat mendukung para penyimpan harta untuk mengkatifkan harta simpanannya (menginvestasikan) dengan cara yang dapat menambah daya produktivitas untuk ekonomi. Dengan demikian pendorong untuk investasi dalam ekonomi Islam lebih kuat dibandingkan dorongan yang ada dalam ekonomi lain. Sebaliknya dukungan zakat terhadap peng-investasian harta dapat menimbulkan terjadinya pengeluaran zakat dari hasil keuntungan bersih investasinya dan perlindungan terhadap aset pokok serta pengembangannya.

Sesungguhnya tujuan akhir pada investasi adalah merealisasikan keuntungan dan pendayagunaan harta dalam aktiviti produktif. Dan keuntungan ini bergantung kepada hubungan antara pendapatan dan pengeluaran sebagai hasil pelaksanaan investasi atau perbandingan antara kecukupan modal dan manfaat (suku bunga) sebagaimana dalam teori Keynes.

Adapun dalam ekonomi Islam, maka suku bunga tidak ada, dan sebagai gantinya adalah bagi hasil (Profit sharing), di sisi lain zakat dianggap

Ulul Albab, Vol. 9 No. 2, 2008 
sebagai perbelanjaan yang diwajibkan dari permodalan yang berkembang. Oleh karena itu maka para ahli korporat dalam kondisi normal akan mengambli langkah-langkah investasi, selagi keuntungan yang diharapan dapat men-jamin minimal perlindungan terhadap jumlah harta setelah mengeluarkan zakat, dalam arti mereka selalu berinvestasi selama tingkat keuntungan mencapai $(2,5 \%)$, yaitu nilai yang terendah bagi zakat yang ditetapkan dalam syariah secara tahunan atas harta, baik secara riil maupun perkiraan.

\section{Pengaruh Zakat terhadap Pertumbuhan Ekonomi}

Al-Qur'an surat at-Taubah ayat 103 menjelaskan bahwa zakat disamping berfungsi membersihkan kekayaan juga menumbuhkan kekayaan. Nabi Muhammad SAW juga bersabda, "Allah menerima zakat dengan tangan kanan-Nya dan kemudian menjadikannya harta itu tumbuh bagi setiap kamu, sebagaimana halnya kamu membesarkan anak kuda atau anak unta. Bagian-bagian harta itu kemudia menjadi sebesar Gunung Uhud." (Hadist Ahmad dan at-Tarmidhi, diriwayatkan oleh Abu Hurairah). Tumbuhnya harta akibat zakat tersebut dapat dijelaskan dengan efek zakat terhadap konsumsi, tabungan, investasi dan ketenagakerjaan serta efek zakat yang bersifat berlipat ganda (multiplier effect) terhadap perekonomian secara keseluruhan.

\section{Efek Zakat terhadap Konsumsi}

Zakat akan meningkatkan konsumsi, terutama konsumsi barangbarang dan jasa-jasa pokok, dan kemungkinan akan menggeser konsumsi dari konsumsi barang-barang dan jasa-jasa mewah kepada konsumsi barangan dan jasa-jasa pokok. Pemberian/pembagian zakat kepada orang miskin dan yang memerlukan memungkinkan pendapatan mereka meningkat. Karena rendahnya tingkat kekayaan dan pendapatan mereka, besar kemungkinan pendapatan dan penerimaan zakat tersebut digunakan untuk pengeluaran konsumsi barangan dan jasa-jasa pokok. Begitu pula 
sebaliknya, zakat akan mengurangkan kekayaan dan pendapatan orangorang kaya. Dengan ber-kurangnya kekayaan dan pendapatan kelompok kaya tersebut, ada kemungkin-an mereka mengurangkan konsumsi barangan dan jasa-jasa mewah. Dengan demikian, secara keseluruhan (aggregat), zakat akan meningkatkan konsumsi barangan dan jasa-jasa pokok dan mengurangkan konsumsi barangan dan jasa-jasa mewah.

\section{Pengaruh Zakat terhadap Ketenagakerjaan}

Pengangguran dianggap sebagai masalah besar dalam perekonomian, sosial dan kemanusiaan yang menempati bahaya yang tinggi. Secara ekonomik, seorang penganggur tidak dapat memperoleh pendapatan untuk memenuhi kebutuhan hidup dan menjadi beban keluarganya. Peningkatan kondisi pengangguran bebarti menimbulkan pertumbuhan jumlah orang yang tidak mendapatkan pendapatan yang akhirnya mengurangi daya permintaan barang dan jasa mereka yang berakibat merosotnya kegiatan perekonomian dan mendekati kebangkrutan, di sisi lain tersedia sumber daya manusia yang produktif.

Secara sosiologi, pengangguran menimbulkan ádanya kélómpok yang mampu dan mencari kerja tetapi mereka menghadapi kondisi pengang. guran dan kekecewaan, lebih-lebih dalam hal pemenuhân kebutuhan pokok, yang mana kondisi ini dapat mengakibatkan timbulnyà keretakan, kecemburuan sosial dan kebencian antara kelompok-kelömpok masyarakat. Begitu juga pengangguran dapat mengancam stabilitas intern masyarakat sebagai konsekuensi tersebarnya rasa kecewa, keputus-asaan, kesia-siaan dan hilangnya kepercayaan diri ditengah-tengah para penganggur.

Dari situlah, maka Islam membenci pengangguran dan menyeru manusia agar mendaparkan pekerjaan dan berjalan di muka bumi serta menganggap bekerja sebagai ibadah dan berjuan di jalan Allah, apabila disertai niat yang benar dan dijaga amanah dan keyakinan. Rasulullah tidak memandang apakah pekerjaan tersebut dianggap hina oleh orang lain atau dipandang remeh seperti mencari kayu bakar. Yang penting pekerjaan yang halal dan terhindar dari kehinaan meminta-minta.

Ulul Albab, Vol. 9 No. 2, 2008 
Zakat memiliki peranan positif dalam peningkatan taraft ketenagakerjaan melalui pengaruhnya dalam seluruh faktor ekonomi yang berhubungan dengan sisi penawaran dan permintaan. Zakat akan meningkatkan penawaran tenaga kerja melalui mekanisme peningkatan peluang investasi, yang mana zakat mendorong masayarakt untuk menginvestasikan dananya yang menganggur, zakat meningkatkan investasi dengan bantuan modal, penambahan investasi sosial dan menjaga investasi yang telah ada. Investasi-investasi ini mengandungi unsur-unsur modal, tanah dan alam yang dapat meningkatkan produktivitas ekonomi dan meningkatkan banyak kesempatan kerja sehingga meningkatkan produktivitas.

Demikian juga diperbolehkannya penggunaan zakat bagi mencari ilmu, maka ia dapat meningkatkan taraf pendidikan dan akan menambah kualitas tenaga kerja, zakat juga dapat meningkatkan permintaan tenaga kerja melalui pengelolaan dan pengurusan zakat, pengelolaan dan pengurusan pertanian dan peternakan serta pemberian modal kerja. Dengan demikian, zakat dapata ikut serta dalam menambah permintaan kerja dan memenuhi peluan

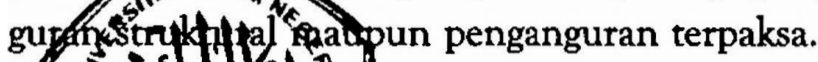

?

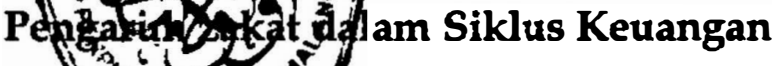

1. besar tana zakat yang murah dan melimpah, akan menjadi pendorong utama berjalannya siklus keuangan secara optimal. Hal itu karena zakat dapat berperan sebagai arus yang terus berputar/berjalan antara pemilik harta dengan yang membutuhkan harta/dengan yang lain, yang kadang kala menyempit dan kadang kala meluas, namun idak terputus selamanya. Arus seperti itu menjadi jaminan dari bahaya kebuntuan dan kemacetan ekonomi dan motor penggerak disebabkan optimalnya siklus keuangan. Hal ini berbeda dengan tabungan, dimana para pemilik harta akan menabung pada saat suku bunga yang tinggi dimana akan mendapatkan hasil yang 
besar dan ini akan merugikan investasi karena biaya bunga yang mahal, dan pemilik harta akan dengan mudah mengalihkan tabungannya pada sektor lain jika kondisi bunga yang rendah.

Selain itu, aktifitas pemerintah dalam investais langsung sebagai salah satu pengelolaan dan pendistribusian zakat berpengaruh besar dalam peningkatan sistem keuangan, dimana sebagai suatu misal saat ini pemerintah indonesia melalui Bank Indonesia sedang mengucurkan dana murah dalam bentuk bantuan UMKM, namun penyerapannya masih sangat rendah, sehingga mengakibatkan terjadi penurunan sikluskeuangan, karena ketidaktakutan, ketidaktahuan masyarakat tentang dana bantuan UMKN, serta ketakutan tidak dapat mengembalikan. Hal ini berbeda dengan zakat, masyarakat yang menerima bantuan akan mendayagunakan zakat tersebut secara optimal karena tidak takut adanya bunga, atau hilangnya harta jaminan. Selain itu, juga untuk meningkatkan pemerataan distribusi pendapatan dikalangan masyarakat, yang saat ini sudah sangat besar dan lebar jurang perbedaannya.

\section{Konsep-konsep Teori Konsumsi}

Ada beberapa ekonom yang mengemukakan konsep tentàng tepri konsumsi, misalnya Keynes, Smithies, Duesenberry, Friedmañi, sërta Arido, Modigliani, dan Blumberg. John Maynard Keynes, dalizu bulkañya "the General Theory of Employment, Interest and Money, mengemükakañ tentang "fundamental psychological law" yang mengarah pada konsumsi dan tabungan.

Keynes berpendapat bahwa jika terjadi tambahan pendapatan nasional masyarakat akan cenderung menggunakan sebagian tambahan pendapatan nasional tersebut untuk membiayai pengeluaran (konsumsi) dan sebagian untuk tabungan. Oleh karena itu ia menyatakan bahwa kecenderungan marginal untuk konsumsi (marginal propensity to consume, MPC), jumlah tambahan konsumsi (belanja) akibat tambahan pendapatan sebanyak satu satuan uang yang nilainya antara 0 sampai dengan 1 . Selain itu Keynes juga menyatakan bahwa bagian pendapatan yang dibelanjakan, atau kecenderungan rata-rata konsumsi (average propensity to consume, APC) proporsi 
konsumsi terhadap pendapatan yang siap untuk dibelanjakan menurun jika pendapatan bertambah.

Arthur Smithies, dalam Absolute Income Theory, memberikan 3 alasan untuk perubahan perilaku konsumsi setelah Perang Dunia II sebagai berikut:

Efek Kekayaan. Konsumsi selama perang dibatasi oleh pemikrian yang rasional dan tidak dapat diperolehnya barang pada saat banyak keluarga yang berperang dan memiliki dua sumber pendapatan (penghasilan dan kekayaan bagi orang yang kaya). Penduduk desa-kota. Penduduk kota mengkonsumsi lebih banyak dibandingkan dengan penduduk desa, karena penghasilan di kota pada umumnya lebih tinggi jika dibandingkan dengan pendapatan di desa. Efek advertensi. Advertensi mempengaruhi konsumen untuk percaya bahwa barang yang semula dianggap mewah menjadi barang penting atau barang normal (misalnya mobil, televisi, dan perabot rumah tangga).

Berdasarkan pendangan Smithies tersebut, keputusan konsumen tergantung pada pendapatan absolut, yaitu pendapatan pada saat melakukän konsumsi dan pendapatan dari stok kekayaan. Pandangan ini berbeda dengan pendapat Keynes yang hanya memperhitungkan pendapatan pada saat melakukan konsumsi.

Dalam relative income theory, James Duesenberry menitikberatkan pada penentuan perilaku konsumen rumah tangga individual. Teori ini mengatakan bahwa keputusan konsumsi individual berkaitan dengan gaya hidup. Kebiasaan konsumsi individual dipengaruhi oleh temgga atau lingkungan kelompoknya, sehingga responsif terhadap perubahan pendapatan. Sedangkan dalam jangka panjang Duesenberry berpendapat bahwa individu yang pendapatannya berubah akan mencari lingkungan yang sesuai dengan tingkat pendapatannya. Dengan pemikirian ini konsumsi akan dipengaruhi secara langsung oleh pendapatan dalam jangka panjang.

Milton Friedman menawarkan pendekatan yang berbeda untuk menjelaskan tentang konsumsi jangka pendek dan jangka panjang. Pendekatan tersebut dinyatakan dalam teori perdapatan permanen (Permanen Income 
Theory). Teori ini membedakan konsumsi barang yang tahan lama dan tidak tahan lama. Friedman juga memiliki hipotesis bahwa perubahan pendapatan yang bersifat sesaat atau mengejutkan tidak akan segera mempengaruhi pola konsumsi. Perubahan pendapatan dalam jangka pendek tidak segera di-gabungkan dengan pendapatan permanen.

\section{Fungsi Konsumsi Keynes}

Dalam suatu perekonomian, pendapatan nasional rumah tangga merupakan sisi pendapatan, sedangkan pengeluaran konsumsi merupakan sisi pengeluaran. Keseimbangan ekonomi tercapai apabila sisi pendapatan sama dengan sisi pengeluaran. Apabila pendapatan rumah tangga diberi simbol $Y$ dan sisi pengeluran diberi simbo $E$, sedangkan pengeluaran konsumsi diberi simbol $\mathrm{C}$, maka keseimbangan dalam perekonomian terjadi apabila: (Algifari, 1998: 74 ).

$$
\begin{aligned}
& Y=E \\
& \text { Karena } E=C, \text { maka } \\
& Y=C
\end{aligned}
$$

Kerangka pemahaman dalam analisis pendapatan nasional yang sangat sederhana ini dapat dibuat dengan menggunakan berbagai asumsi terhadap indikator yang membentuk pendapam nasional tersebut. Misalnya asumsi terhadap pola konsumsi rumah tangga yang konstan selama periode analisis. Dengan demikian, bentuk kurva pengeluaran konsumsi rumah tangga yang menunjukkan hubungan antara pengeluaran rumah tangga dengan pendapatan nasional adalah linear, seperti yang dikemukakan oleh Keynes. Menurut Keynes, pengeluaran konsumsi rumah tangga sangat dipengaruhi oleh besarnya pendapatan yang ia terima. Secara matematis dapat ditulis sebagai berikut:

$$
C=f(Y)
$$

Ulul Albab, Vol. 9 No. 2, 2008 
Dengan ketentuan:

$$
b=M P C=\frac{\Delta C}{\Delta Y}
$$

Rasio antara perubahan pengeluaran konsumsi $(\Delta \mathrm{C})$ dengan perubahan pendapatan nasional $(\triangle \mathrm{Y})$ lebih besar dari nol mengandung pengertian bahwa pengeluaran konsumsi rumah tangga akan meningkat secara proporsional apabila terjadi peningkatan pendapatan. Sedangkan rasio antara perubahan pengeluaran konsumsi $(\Delta C)$ dengan perubahan pendapatan nasional $(\Delta \mathrm{Y})$ lebih kecil dari satu mengandung pengertian bahwa kenaikan pengeluaran konsumsi rumah tangga tersebut selalu lebih kecil dari pada kenaikan pendapatan. Besarnya rasio perubahan pengeluaran konsumsi rumah tangga dan perubahan pendapatan rumah tangga ini dalam analisis pendapatan nasional disebut hasrat/keinginan dari rumah tangga tersebut dalam berkonsumsi. Besarnya hasrat/ keinginan dari rumah tangga tersebut dalam berkonsumsi ini disebut hasrat marjinal berkonsumsi (Marginal Propensity to Consume $=$ MPC ). Jadi, MPC menunjukkan perbandingan antara besarnya perubahan pengeluaran konsumsi rumah tangga dengan besarnya perubahan pendapatan. Besarnya MPC adalah lebih besar dari nol dan lebih kecil dari satu $(0<\mathrm{MPC}<1)$.

Keynes membuat fungsi konsumsi sebagai pusat teori fluktuasi ekonominya, dan teori itu telah memainkan peran penting dalam analisis makroekonomi sampai saat ini. Dugaan Keynes tentang fungsi konsumsi dapat dijelaskan sebagai berikut (Gregory, 2000: 399-401):

a. kecenderungan mengkonsumsi marjinal (marginal propensity to consume) adalah antara nol dan satu.

b. rasio konsumsi terhadap pendapatan atau kecenderungan mengkonsumsi marginal (average propensity to consume), turun ketika pendapatan naik.

c. pendapatan merupakan determinan konsumsi yang penting dan tingkat bunga tidak memiliki peran yang penting 
Berdasarkan analisis di atas, keynes mengemukakan bentuk kurva kon-sumsi ditunjukkan oleh persamaan:

$$
\mathrm{C}=\mathrm{a}+\mathrm{bY}
$$

$a$ dan $b$ adalah konstan untuk $a>0 ; 0<b<1$

yang menyatakan bahwa:

$\mathrm{C}=$ besarnya pengeluaran konsumsi rumah tangga

$\mathrm{a}=$ besarnya pengeluaran konsumsi rumah tangga apabila pendapatan masyarakat tidak ada (konsumsi otonom)

$\mathrm{b}=\mathrm{MPC}=$ hasrat marjinal dari masyarakat untuk melakukan konsumsi (MPC = Marginal Propensity to Consume)

$$
\mathrm{MPC}=\left(\frac{d C}{d Y}\right)_{z=0}=\mathrm{b}
$$

Berdasarkan tiga dugaan tersebut, fungsi konsumsi dapat ditulis sebagai berikut:

\section{Fungsi Konsumsi Linier}

a. Fungsi Konsumsi Linear Konvensional

Katakanlah fungsi konsumsi untuk ekonomi non-Islam (tidak ada zakat dan tidak ada tindakan fiskal yang sama dengan itu, maka $Z=0$ ) adalah sebagai berikut:

$$
\mathrm{C}=\mathrm{a}+\mathrm{bY}
$$

dimana :

$\mathrm{C}=$ konsumsi; $\mathrm{Y}=$ Pendapatan

$a$ dan $b$ adalah konstan untuk $a>0 ; 0<b<1$

Dalam kasus ini maka kita memperoleh hasrat konsumsi rata-rata:

Ulul Albab, Vol. 9 No. 2, 2008 


$$
\operatorname{APC}=\left(\frac{C}{Y}\right)_{z=0}=\frac{T}{Y}+b
$$

dan hasrat konsumsi marginal:

$$
\mathrm{MPC}=\left(\frac{d C}{d Y}\right)_{z=0}=\mathrm{b}
$$

\section{Fungsi Konsumsi Non - Linier}

a. Fungsi Konsumsi Non-Linear dalam Ekonomi Konvensional

Fungsi konsumsi non-linier yang lebih realistis dengan persyaratan/ asumsi sebagai berikut:

i) Untuk $Y=0 ; C=0$

ii) $\frac{C}{Y}>0$ tetapi $\frac{d}{d Y}\left(\frac{C}{Y}\right)<0$

iii) $\frac{d C}{d Y}>0$ retapi $\frac{d^{2} C}{d Y^{2}}\left(\frac{C}{Y}\right)<0$

Dengan kata lain, tingkat konsumsi otonom/outonomus (positif) dan hasrat konsumsi rata-rata dan hasrat konsu msi marginal adalah positif, tetapi menurun dengan meningkatnya pendapatan. Implikasi dari ketiga asumsi diatas adalah:

$$
0<\left(\frac{d C}{d Y}\right)<\left(\frac{C}{Y}\right)
$$

sehingga sebuah fungsi yang memenuhi persyaratan tersebut adalah:

$$
\mathrm{C}=\mathrm{a}+\mathrm{gY}^{\mathrm{b}}
$$

Dimana : $a>0, g>0,0<b<1$

Dalam ekonomi non Islam (tidak ada zakat dan tidak ada kebijakan fiskal sejenis yang mirip dengan itu), diperoleh: 


$$
\begin{aligned}
& \mathrm{APC}=\left(\frac{C}{Y}\right)_{z=0}=\frac{a}{Y}+\mathrm{gY}^{b-1} \\
& \mathrm{MPC}=\left(\begin{array}{l}
d C \\
d Y
\end{array}\right)_{z=0}=b g Y^{b-1}
\end{aligned}
$$

\section{Teori Konsumsi dalam Islam}

Konsumsi adalah permintaan sedangkan produksi adalah penyediaan/ penawaran (Mannan, 1997: 44). Kebutuhan konsumen, yang kini telah diperhitungkan sebelumnya, merupakan insentif pokok bagi kegiatankegiatan ekonominya sendiri. Mereka mungkin tidak hanya menyerap pendapatannya, tetapi juga memberi insentif untuk meningkatkannya. Hal ini mengandung arti bahwa pembicaraan mengenai konsumsi adalah primer dan hanya bila para ahli ekonomi mempertunjukkan kemampuannya untuk memahami, dan menjelaskan prinsip produksi maupun konsumsi sajalah, mereka dapat dianggap kompeten untuk mengembangkan hukum-hukum nilai dan distribusi atau hampir setiap cabang lain dari subjek tersebut. Menurut Manan, perbedaan antar ilmu ekonomi modern dan ekonomi Islam dalam hal konsumsi terletak pada cara pendekatannya dalam memenuhi kebutuhan seseorang. Islam tidak mengakui kegemaran materialistis semata-mata dari pola konsumsi modern.

Sejumlah ekonom Muslim diantaranya adalah Zarqa (1980 dan 1982), Monzer Kahf (1978 dan 1980), M.M Metwally (1981), Fahim Khan (1988), M.A. Manan (1986), M.A. Choudhury (1986), Munawar Iqbal (1986), Bnedjilali dan Al-Zamil (1993) dan Ausaf Ahmad (1992) telah berusaha untuk memformulasikan fungsi konsumsi yang mencerminkan faktor-faktor tambahan ini meki tidak seluruhnya. Mereka beranggapan bahwa tingkat harga saja tidaklah cukup untuk mengurangi tingkat kunsumsi barang mewah $\left(C_{1}\right)$ yang dilakukan oleh orang-orang kaya. Diperlukan cara untuk merubah sikap, selera dan preferensi, memberikan motivasi yang tepat, serta mencipta-kan lingkungan sosial yang memandang buruk konsumsi seperti itu $\left(C_{1}\right)$.

Ulul Albab, Vol. 9 No. 2, 2008 


\section{Fungsi Konsumsi Linear dalam Ekonomi Islam}

Menurut Metwally fungsi konsumsi dalam ekonomi Islam, untuk menyederhanakan masalah, dianggap besarnya zakat ditunjukkan oleh fungsi:

$\mathrm{Z}=\alpha \mathrm{Y}$

di mana :

$0<\alpha<1$

Katakanlah $\beta Y$ merupakan pendapatan pembayaran zakat yang menguasai satu bagian tertentu dari pendapatan nasional; dan sisanya (1-b)Y adalah pendapatan penerima zakat, dimana: $0<\beta<1$

Dimisalkan juga sebagai hasrat konsumsi marginal penerima zakat, dimana: $0<\beta<1$

Fungsi konsumsi dalam ekonomi Islam (9.3) dengan mensubstistusikan persamaan (9.6) menjadi :

$$
C=a+b(\beta Y-\alpha Y)+\delta[(1-\beta) Y+\alpha Y]
$$

Untuk ekonomi Islam akan diperoleh persamaan:

$$
\begin{aligned}
& \mathrm{APC}=\left(\frac{C}{Y}\right)_{z>0}=\frac{a}{Y}+\mathrm{b} \beta-\alpha \mathrm{b}+\delta(1-\beta)+\alpha \beta \\
& \mathrm{MPC}=\left(\frac{d C}{d Y}\right)_{z>0}=b \beta-\alpha b+\delta(1-\beta)+\alpha \beta
\end{aligned}
$$

Jika ditelusuri persamaan (9.4), (9.5), (9.7) dan (9.8) maka akan diperoleh:

$$
\begin{aligned}
& \left(\frac{C}{Y}\right)_{z>0}-\left(\frac{C}{Y}\right)_{z=0}=\delta(1+\alpha-\beta)-b(1+\alpha \beta) \\
& \left(\frac{d C}{d Y}\right)_{z>0}-\left(\frac{d C}{d Y}\right)_{z=0}=\delta(1+\alpha-\beta)-b(1+\alpha-\beta)
\end{aligned}
$$


jelaslah $\left(\frac{C}{Y}\right)_{z>0}>$ dan >

selama $\delta>\beta$ maka persyaratan di atas akan selalu terpenuhi.

\section{Fungsi Konsumsi Non-Linear dalam Ekonomi Islam}

Dalam ekonomi Islam diperoleh persamaan:

$$
\begin{aligned}
& \mathrm{C}=\mathrm{a}+\mathrm{g}(\beta-\alpha) \mathrm{Y}^{\mathrm{d}}+\mathrm{g}(1-\beta+\alpha) \mathrm{Y}^{\delta} \\
& \mathrm{APC}=\left(\frac{C}{Y}\right)_{z>0}=\frac{a}{Y}+\mathrm{g}(\beta-\alpha) \mathrm{Y}^{\mathrm{d}-1}+\mathrm{g}(1-\beta+\alpha) \mathrm{Y}^{\delta-1} \\
& \mathrm{MPC}=\left(\frac{d C}{d Y}\right)_{Z>0}=\operatorname{bg}(\beta-\alpha) \mathrm{Y}^{\alpha-1}+\delta \mathrm{g}(1-\beta+\alpha) \mathrm{Y}^{\delta-1}
\end{aligned}
$$

Dari persamaan di atas

$$
\begin{aligned}
& \left(\frac{C}{Y}\right)_{z>0}-\left(\frac{C}{Y}\right)_{z=0}=\mathrm{g}(1+\alpha-\beta)\left(Y^{\delta-1}-Y^{d-1}\right) \\
& \left(\frac{d C}{d Y}\right)_{z>0}-\left(\frac{d C}{d Y}\right)_{z=0}=\mathrm{g}(1+\alpha-\beta)\left(\delta Y^{\delta-1}-Y^{d-1}\right)
\end{aligned}
$$

untuk $d>0$, maka

$$
\left(\frac{C}{Y}\right)_{z>0}>\left(\frac{C}{Y}\right)_{z=0}
$$




$$
\operatorname{dan}>\left(\frac{d C}{d Y}\right)_{Z>0}>\left(\frac{d C}{d Y}\right)_{Z=0}
$$

juga untuk $d>b$, maka

$$
\begin{aligned}
& \frac{d}{d Y}\left(\frac{C}{Y}\right)_{z>0}>\left(\frac{d C}{d Y}\right)_{Z=0}=\mathrm{g}(1-\alpha-\beta)\left[\delta(\delta-1) \mathrm{Y}^{\sigma-2}-\mathrm{b}(\mathrm{b}-1) \mathrm{Y}^{\mathrm{b}-2}\right)>0 \\
& \left(\begin{array}{l}
d^{2} C \\
d Y^{2}
\end{array}\right)_{Z=0}<\left(\begin{array}{l}
d^{2} C \\
d Y^{2}
\end{array}\right)_{Z=0}=\mathrm{g}(1-\alpha-\beta)\left[\delta(\delta-1) \mathrm{Y}^{\delta-2}-\mathrm{b}(\mathrm{b}-1) \mathrm{Y}^{\mathrm{b}-2}\right)>0(9 .
\end{aligned}
$$

Siddiqi dan Kahf menyebutkan bahwa dengan adanya zakat maka hasrat konsumsi rata-rata dan hasrat marginal dalam jangka pendek akan menurun tapi penurunan ini lebih kecil di ekonomi Islam dibandingkan dengan ekonomi non-Islam yang tidak punya tindakan fiskal yang sama, tetapi dalam jangka panjang tingkat konsumsi masyarakat akan mengalami peningkatan karena: Pertamo, taraf hidup masyarakat penerima zakat akan meningkat. Penurunan konsumsi tersebut disebabkan oleh permintaan akan barang-barang mewah yang menurun.

Kedua, permintaan akan barang-barang pokok dari masyarakat tersebut akan meningkat seiring meningkatnya taraf hidup masyarakat yang menerima zakat. Namun, ajaran Islam tidak menganjurkan konsumsi boros, dan barang mewah, dan ingat tentang hari kemudian (akhirat). Ajaran Islam dalam batas-batas tertentu dapat mengimbangi efek zakat terhadap konsumsi.

\section{Tabungan}

Tabungan dengan tidak adanya bunga tidak dapat dimobilisasi untuk pembentukan modal. Oleh karena itu, keperluan akan modal berbunga sebenarnya timbul dengan perkembangan industri dan perdagangan secara besar-besaran (Mannan, 1997: 64). Serangan paling tajam terhadap 
pendirian ini datang dari Keynes, yang menolak bahwa tabungan itu sendiri memerlukan suatu rangsangan dalam bentuk bunga. Dia menyatakan bahwa sebagian besar tabungan bersifat sukarela dengan demikian tidak memerlukan imbalan khusus berupoa uang. Bahkan jika diakui bahwa suku bunga mempunyai sedikit pengaruh terhadap tabungan marjinal, pendirian neo klaik itu telah diruntuhkan oleh anggapan tentang pendapatan tetap. Keynes telah mencoba membuktikan bahwa tabungan dan investasi selalu harus tetap sama; persamaan antara keduanya itu disebabkan oleh perubahan dalam tingkat pendapatan sebagai akibat inveswasi.

Lebih lanjut Mannan mengemukakan bahwa bahkan dengan tidak adanya rangsangan bunga, mungkin terdapat lebih banyak tabungan dan investasi, dan berakibat lebih banyak pendapatan, sebagian karena daya tarik sisa laba yang lebih tinggi, sebagian lagi karena kurangnya resiko kerugian. Karena peran serta rakyat yang langsung dalam proses produksi, maka hasil investasi mencukupi dan adil tanpa sebagian besar daripadanya dieksploitir oleh kapitalis. Selanjutnya keputusan mengenai pembuatan kebijakan yang begitu luas dan dipertanggungjawabkan bersama, menyebabkan berkurangnya peluang investasi yang tidak bijaksana dan berbahaya, dan dengan demikian akan mengurangi resiko kerugian sekecilkecilnya.

Penanaman spirit Islam pada semua ting-katan masyarakat akan mengurangi klaim pada sumber-sumber daya, termasuk cadangan devisa, dan akan mendorong tabungan dan formasi kapital. Hal ini juga akan mengurangi permintaan kredit (bukan saja untuk tujuan-tujuan konsumsi pamer, yang tidak meluas tersebar di negara-negara berkembang, tetapi juga impor, produksi, dan distribusi barang-barang demikian) dan karena itu adalah ekspansi moneter yang tidak perlu. Pelanggaran terhadap nilainilai Islam oleh sebagian orang sekalipun akan cenderung melonggarkan ikatan sosial untuk memperoleh simbol-simbol prestise, sehingga mempertajam nafsu ketamakan dan kedengkian (Monzer, 1997: 79).

Selain itu, kahf juga menyebutkan bahwa pengeluaran yang berlebihan dilarang, penimbunan simpanan juga dikecam tegas oleh al-Qur'an dan 
asSunnah. Sumbersumber daya yang telah disediakan Allah harus dipergunakan untuk kegunaan si empunya (dalam batas-batas yang ditetapkan oleh lslam) atau peruntukan bagi orang lain, sehingga memenuhi tujuan dasar penciptaannya. Membiarkannya menganggur dan tidak memanfaatkannya bagi tujuan-tujuan konsumsi yang benar atau untuk pengembangan barang-barang umum lewat kontribusi kesejahteraan (zakat, sedekah, dan pembayaran semacamnya) atau untuk investasi produktif telah dikecam oleh Islam.

\section{Tabungan Agregat dalam Ekonomi Konvensional}

Kecenderungan menabung rata-rata (APS) adalah tingkat tabungan dibagi pendapatan nasional, dan kecenderungan menabung marjinal (MPS) adalah turunan pertama dari tingkat tabungan. Tanpa adanya zakat harta perniagaan sebagai pengurang pajak, nilai APS dan MPS dapat dinyatakan sebagai:

$$
\begin{aligned}
\mathrm{APS} & =\left(\frac{S}{Y}\right)_{Z=0}=1-\frac{a}{Y}+\mathrm{b} \beta-b t \beta+\delta-\delta t+\delta t \beta \\
\mathrm{MPS} & =\left(\frac{d S}{d Y}\right)_{Z=0}=1-\mathrm{b} \beta-b t \beta+\delta-\delta t+\delta t \beta
\end{aligned}
$$

\section{Tabungan Agregat dalam Ekonomi Islam}

Zakat perniagaan $z \mathrm{Y}$, di satu sisi akan mengurangi penghasilan kena pajak muzakki, dan di sisi lain tidak termasuk objek pajak yang wajib bagi mustahiq. Oleh karena itu persamaan-persamaan di atas dapat ditulis kembali menjadi:

$$
S=Y-a+b \beta Y-b \alpha Y-b t \beta Y+b \alpha Y+\delta Y-\delta \beta Y-\delta t Y+\delta \alpha Y+\delta t \beta Y
$$

Kecenderungan menabung rata-rata (APS) adalah tingkat tabungan dibagi pendapatan nasional, dan kecenderungan menabung marjinal (MPS) 
adalah turunan pertama dari tingkat tabungan. Dengan adanya zakat harta perniagaan sebagai pengurang pajak, nilai APS dan MPS dapat dinyatakan sebagai:

$\operatorname{AS}=\left(\frac{S}{Y}\right)_{2>0}=1-\frac{a}{Y}+\mathrm{b} \beta-b \alpha-b t \beta+b t \alpha+\delta-\delta \beta-\alpha+\delta \alpha+\alpha \beta$

MPS $=\left(\frac{d S}{d Y}\right)_{200}=1-\mathrm{b} \beta-b \alpha-b \phi \beta+b \mathrm{t} \alpha+\delta-\delta \beta-\delta t+\delta \alpha+\delta t \beta(10.8)$

Bedasarkan kajian di atas, fungsi tabungan dalam ekonomi Islam dapat dibuat lebih mudah sebagai berikut:

Tulis kembali persamaan (10.1) di atas:

$$
\begin{aligned}
& \mathrm{S}=\mathrm{Y}-\mathrm{C} \\
& \mathrm{S}=\mathrm{Y}-\mathrm{C}_{1}-\mathrm{Z}-\mathrm{E} \\
& S=-a+(1-z-\gamma)(1-b) Y
\end{aligned}
$$

jika I = I ${ }^{0}$ maka:

$$
\begin{aligned}
& -a+(1-z-\gamma)(1-b) Y=I^{0} \\
& Y=\frac{1}{(1-z-\gamma)(1-b)}\left(a+I^{0}\right)
\end{aligned}
$$

Ulul Albab, Vol. 9 No. 2, 2008 
S

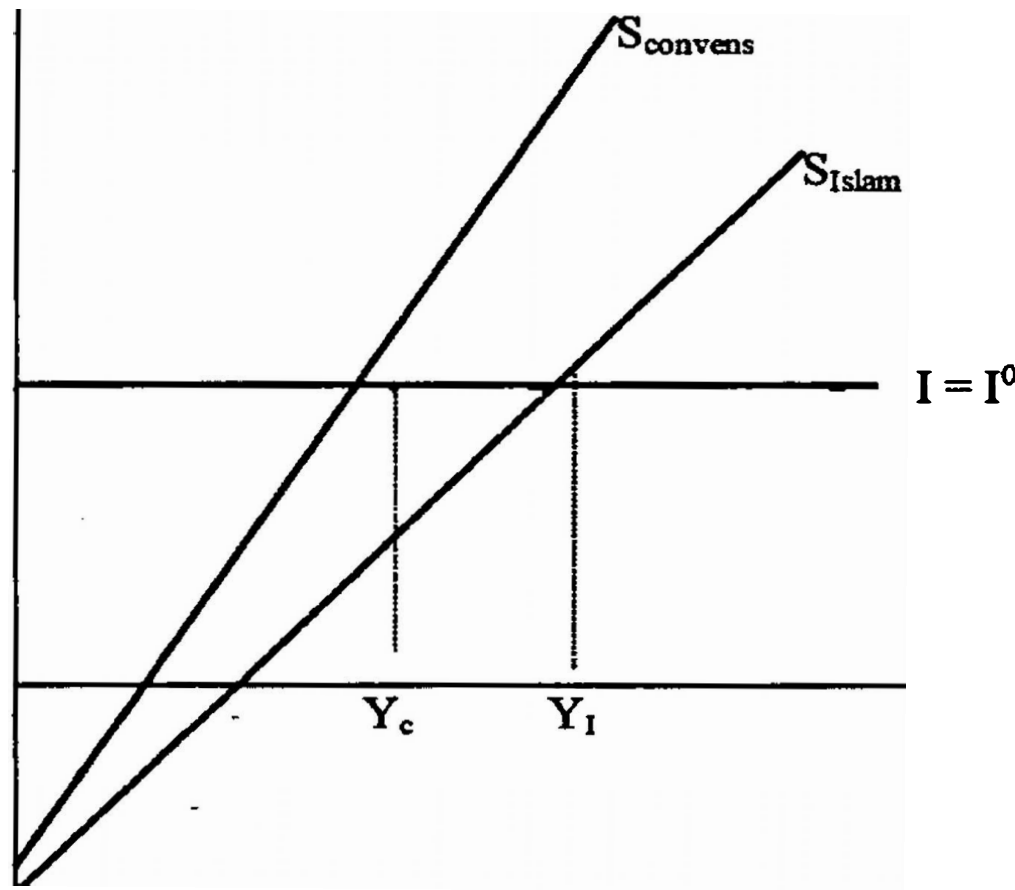

- a

Gambar 1. Penentuan Pendapatan melalui Tabungan dan Investasi dalam_. ekonomi non - Islam dan ekonomi Islam

Gambar 1 proses penentuan pendapatan di dalam suatu ekonomi Islam dapat juga diuji dengan bantuan suatu diagram. Diasumsikan kondisi ekonomi berada pada perekonomian tertutup, tabungan agregat (Saving) diukur pada garis yang vertikal dan pendapatan agregat sepanjang garis horisontal di dalam gambar (2). Investasi adalah otonom sebesar $\mathrm{I}^{0}$ ditunjukkan dengan garis lurus horisontal. Garis $S_{c}$ menunjukkan tabungan pada perekonomian non-Islam, dengan slope sebesar (1-b), sedangkan Garis $S_{l}$. merupakan kurva tabungan pada perekonomian Islam, dengan slope 
sebesar $(1-z-g)(1-b)$. Hal ini memberikan gambaran bahwa slope tabungan dalam ekonomi Islam lebih kecil dari pada slope tabungan pada ekonomi non-Islam. Keseimbangan pendapatan terjadi pada tingkat $Y_{C}$ untuk perekonomian non-Islam, sedangkan dalam ekonomi Islam keseimbangan pen-dapatan terjadi pada tingkat $Y_{1}$, dimana nilai $Y_{1}$ lebih besar dari nilai $Y_{c}$.

\section{Agenda strategis}

Ada dua agenda yang mendesak dilakukan untuk memperkuat eksistensi dan kedudukan organisasi zakat di Indonesia untuk mengembangkan zakat. Pertama, memperkuat infrastruktur di masing-masing negara propinsi dan daerah tigkat II. Infrastruktur yang dimaksud juga mencakup aspek regulasi dan peraturan, pendidikan dan SDM, serta sarana dan prasarana lain yang dibutuhkan, termasuk sosialisasi dan kampanye zakat yang intensif.

Dalam aspek regulasi dan peraturan misalnya, kedudukan lembaga zakat di suatu negara harus diperkuat. Kalau kita melihat Malaysia, maka negara-negara bagian yang ada di Malaysia memiliki pusat zakat yang kuat secara hukum dan politik, serta mendapat dukungan penuh pemerintah. Dukungan itu antara lain dalam bentuk pengalokasian anggaran negara, penerapan kebijakan 'zakat sebagai pengurang pajak' secara nyata di lapang. an, dan pemberian kemudahan akses bagi muzakki untuk membayar zakat. Kemudian, dukungan lainnya berupa penyusunan database yang valid mengenai jumlah muzakki dan mustahik.

Selanjutnya, kalau kita melihat negara-negara Arab, maka pada umumnya status kelembagaan yang mengelola zakat adalah setingkat kementerian. Sebagai contoh adalah Kuwait dan Qatar serta Malaysia. Ini menunjukkan besarnya perhatian terhadap institusi.zakat yang ada. Kita berharap Indonesia dapat mengambil pelajaran dari Malaysia dan dunia Arab dalam memperkuat institusi zakatnya. 
Status Baznas hendaknya ditingkatkan menjadi kementerian. Bahkan beberapa praktisi zakat mengusulkan kalau memang dianggap memberatkan anggara $n$ negara, maka kementerian zakat ini tidak perlu dibiayai APBN. Yang terpenting diberikan kekuatan untuk 'memaksa' muzakki membayar zakat. Mereka berargumen bahwa selama ini pun, seluruh lembaga zakat yang ada telah mampu berkiprah secara mandiri. Fakta pun membuktikan, meskipun dana zakat yang terhimpun masih kecil, tetapi manfaatnya dapat dirasakan secara nyata oleh masyarakat.

Agenda kedua adalah menciptakan mekanisme penghimpunan dan pendayagunaan zakat serta koordinasi antar negara Islam. Salah satu tujuan dibentuknya organisasi zakat internasional ini adalah teralirkannya dana zakat dari negara-negara surplus zakat ke negara-negara minus zakat. Untuk itu perlu dibuat aturan yang jelas mengenai kriter! ia dan mekanisme aliran dana tersebut.

Jika aliran dana tersebut ditentukan berdasarkan program yang diajukan, maka indikator dan kriteria program yang dapat diajukan pun harus jelas. Jika mekanisme ini disepakati, maka Indonesia dapat memanfaatkan peluang yang ada dengan membuat berbagai proyek percontohan pemb erdayaan kaum dhuafa. Yang juga tidak kalah penting adalah menentukan share masing-masing negara dalam proses penghimpunan dana zakat. Penulis berkeyakinan, organisasi zakat ini jika terbentuk, akan memiliki peran yang sangat strategis dan vital dalam mengembangkan perekonomian umat di masa mendatang.

\section{Simpulan}

Kapitalisme dan Sosialisme yang selama ini ada telah gagal menjalankan tugasnya sebagai jalan menuju kesejahteraan dan keadilan karena meng. abaikan dimensi motral sebagai salah satu landasannya.Pajak dalam sistem perekonomian berfungsi sebagai penyediaan dana dan) mewujudkan beban pajak yang mencerminkan kepuasan masya-rakat terhadap suatu barang publik. Sedangkan zakat hanya sebagai penyedia dana yang penggunaannya sudah ditentukan oleh hukum Islam (al-Qur,an) Zakat memiliki pengaruh 
yang besar dalam perekonomian baik per-tumbuhan ekonomi, konsumsi, pemberantasan penimbunan, ketenaga-kerjaan, investasi dan sebagainya. Zakat secara ekonomi makro mampu memberikan peningkatan pendapatan baik secara langsung maupun tidak langsung.

\section{Daftar Pustaka}

Agustianto. 2002. Percikan Pemikiran Ekonomi Islam. Bandung.

Agustianto. 2006. The Death Of Economics Dan Chance Ekonomi Syariahy.(Online), urww.pesantrenvirtual.com.

Algifari, GM. 1998. Teori Ekonomi Makro. Yogyakarta: BPFE UGM.

Chapra, U. 2002. The Future of Economics: An Islamic Perspective: Lanscape Baru Perekonomian Masa Depan. Jakarta: Tim Penerbit SEBI.

Harian Republika. 19 Januari 2004.Data Bank Indonesia. hal. 16.

Harian Republika. 6 Januari 2004. Data Direktorat Bank Syari'ah Bank Indonesia. hal. 16.

Gregory, M. 2000. Teori Ekonomi Makro. Terjemahan oleh Imam Nurmawan. Edisi Keempat. Jakarta: Penerbit Erlangga.

Mannan, MA. 1997. Teori dan Praktek Ekonomi Islam, Yogyakarta: PT. Dana Bhakti Wakaf.

Monzer, K. 1989. Zakat in Macro Economic Context. (Online), unuru.kahf.net/ articles/english/. 